\title{
A Generic Construction of the Right System for Population Ageing: Draft Convention on the Rights of the Elderly
}

\author{
Lin Zhang* \& Jingjing An**
}

\begin{abstract}
Although there are many international treaties and conventions offering protection for generic human rights that implicitly refer to older persons, these relevant provisions are scattered, porous and lack of practical operability, which fail to provide explicit, tailored, comprehensive and binding protection to older persons. In addition, there are some soft law provisions that guide the application of law and add to the overall protection of older people. However none of the documents contains legally binding obligations. Therefore, the protection of the rights of the elderly must be formulated as the "hard law" which defines the responsibilities of the state and clarifies the implementation mechanism at the international and domestic level. In other words, a legal system ought to be established to comprehensively protect the rights of the elderly, which is just the Convention on the Rights of the Elderly. This article attempts to present a proposal to create the right system of the Convention, which represents the core of this potential international treaty.
\end{abstract}

\section{Keywords}

Right System, Population Ageing, Convention on the Rights of the Elderly, CRE, Construction

* Distinguished Professor of the School of Law and Economics at Shandong University of Technology. LL.B./ LL.M.(Shandong Univ. of Sci. \& Tech.: "SDUST"), Ph.D. (UHK). ORCID: http://orcid.org/0000-0001-9237-4939. The author may be contacted by email at: linzhang@sdut.edu.cn/Address: Room 308 West, Teaching Building No. 2, Shandong University of Technology, No. 266 Xincun West Road, District of Zhangdian, City of Zibo 255000, Shandong Province, P.R.China.

** Corresponding Author. Assistant Professor at the School of Law of Shandong University of Technology. LL.B./LL.M. (SDUST), Ph.D. (Korea U.). She may be contact at: ajj1983@163.com All the websites cited in this article were last visited on May 19, 2020. 


\section{Introduction}

Population ageing is growing at an accelerated speed on the international level nowadays. Under such circumstances, the appeal to create the Convention on the Rights of the Elderly ("CRE") by the UN has been increasingly reinforced by various stakeholders. The rights system is the point of contention in the process. The population ageing faces special and urgent human rights challenges such as ageism, isolation, violence and abuse. While ageing society is processing intensively, each challenge has become more serious due to the deficiencies in the normative and practical framework for protecting their human rights. ${ }^{1}$ These challenges involve all aspects of civil, political, economic, social and cultural rights. The construction of the rights system will: promote, deepen and more accurately define the rights of the elderly; strengthen the obligation to respect; protect and implement the rights stipulated; provide greater visibility and recognition for the elderly at home and abroad; and lay a solid foundation for the support of the rights of the elderly and the promotion of public awareness and human rights education.

The primary purpose of this research is to present a proposal of creating the right system of the CRE, which represents the key part of this highly expected international treaty. This paper consists of five parts including Introduction and Conclusion. Part two will discuss the unique features of the right system of the elderly. Part three will examine the efforts made by the UN to protect the rights of the elderly and the flaws of these endeavors. Part four will propose the plan to systematically construct the right system of the CRE.

\section{Unique Features of the Right System of the Elderly}

The CRE will be a new core international human rights convention. ${ }^{2}$ By examining the existing human rights framework and mechanism of the UN, the categories of human rights should be tailored according to the characteristics of older persons and the particularity of their rights infringed, and additionally construct a protection mode suitable for the unique situation of older persons. Therefore, the characteristics

I. Doron, The Debate Around the Need for an International Convention on the Rights of Older Persons, 5 Gerontologist 586-93 (2010).

2 Id. 
of each right should be clearly defined so as to ensure the particularity of the applicable object. The construction of the rights system of the elderly contain the following aspects:

\section{A. Thoroughness and Comprehensiveness}

In December 2012, the 67th General Assembly of the UN authorized the Open-ended Working Group on Ageing to call for "special measures without delay to strengthen the international protection system for the elderly, including the preparation of a new specialized international instrument, namely, a thorough and comprehensive international legal instrument to promote and protect the rights and dignity of the elderly."3

The term 'thorough' implies a holistic approach to the elaboration of the CRE. The term 'comprehensive' means that the CRE should be the core component of international human rights law, rather than the subsidiary of existing human rights law, having the same status as other core human rights conventions. ${ }^{4}$ Therefore, in the construction of the rights system, various rights should be interdependent, complementary and mutually reinforcing, and jointly build a complete framework for the protection of the rights of the elderly.

The construction of the rights system of the CRE complies with the combination of comprehensiveness and integrity, which fully conforms to the interdependence and indivisibility of human rights attributes. If one right is deprived and restricted, the other rights are bound to be difficult to fully enjoy. ${ }^{5}$ For example, without economic, social and cultural rights, no people will claim and enjoy civil and political rights. ${ }^{6}$ At the core of human rights is freedom and equality. Freedom and equality cannot just be limited to civil and political relations, but also include economic and social dimensions. If social and economic security is not guaranteed, the civil and political rights will be also irrelevant. ${ }^{7}$ In 1993, the World Conference on Human Rights in Vienna reiterated that "all human rights are universal, indivisible, interdependent

3 G.A. Res. 67/139, U.N. Doc. A/RES/67/139 (Feb.13,2012): Establishment of a Thorough and Comprehensive International Legal Instrument for the Promotion and Protection of the Rights and Dignity of Older Persons, available at https://www.un.org/zh/documents/view_doc.asp?symbol=A/RES/67/139\&Lang=E. [Emphasis added]

$4 \quad$ Id.

5 X. Junyong, Lectures on International Human Rights Law [国际人权法讲义] 29 (2013).

$6 \quad I d$.

7 M. Scheinin, International Human Rights Law, in A Companion to European Union LaW and InTERnational LaW ch. 29 (D. Patterson \& A. Södersten eds., 2016), available at https://doi.org/10.1002/9781119037712.ch29. 
and interrelated." ${ }^{\circ}$ The international community must treat human rights in an equal and fair manner, with the same emphasis attitude. ${ }^{9}$ The relevant UN conferences have so paid full attention to this point in their discussions on the protection of the rights of the elderly, recognizing that: "all human rights are interrelated and interdependent. Without economic, social and cultural rights, it is impossible to exercise civil and political rights, and vice versa." 10

Therefore, the construction of the rights system of the CRE should not only break through the traditional content of human rights about the distinction between "the first generation of human rights (civil and political rights)" and "the second generation of human rights (economic, social and cultural rights)," but also integrate civil and political rights into economic, social and cultural rights in the whole structure of each article. In addition, it should build a high-level, comprehensive system for protecting the rights of the elderly.

\section{B. Personality and Human Prosperity}

Personality is the state of being of a person. It is closely related to the legal and political concepts such as citizenship, equality and freedom. ${ }^{11}$ In ancient Rome, Roman jurists and magistrates used the word 'Capn' to express personality, implying that personality is to people as the head is to life. ${ }^{12}$

To construct the rights system of the elderly, traditional personality should be redefined following the broader life process in the whole society. First of all, the cognitive and behavioral abilities of the elderly would gradually decrease with age. At the same time, how to support older persons to practice feasible rights such as classifying legal rights should be explored so that the legal guardians of the elderly can use them restrictively. State Parties are obliged to take facilitative measures to assist older persons to acquire the capacity they may need to exercise their legal rights according to international human rights law. They need to establish an

8 OHCHR, World Conference on Human Rights, Vienna, Austria (June 14-25, 1993), available at https://www.ohchr. org/EN/ABOUTUS/Pages/ViennaWC.aspx.

9 V. Randall, The Vienna Declaration and Program of Action with Background Information, 8 WASH. \& LEE. J. C.R. \& Soc. Just. (2002).

10 Report of the 2014 Social Forum of the UN General Assembly, U.N.Doc. A/HRC/26/46 (May 15, 2014), available at https://www.ohchr.org/EN/HRBodies/HRC/RegularSessions/Session26/ layouts/15/WopiFrame.aspx?sourcedoc=/EN/ HRBodies/HRC/RegularSessions/Session26/Documents/A_HRC_26_46_ENG.DOC\&action=default\&DefaultItemOp en $=$.

11 C. Taylor, The Concept of a Person, Philosophical Papers: Volume 1: Human Agency and Language 97 (1985).

12 W. Liming, On the New Development of Personality Rights [试论人格权的新发展], 5 L. \& Bus. Stud. [法商研究] 16 (2005). 
independent and impartial body to conduct periodic reviews. In this regard, legal rights and integrity of the elderly can be fully exercised for them to participate in social activities. ${ }^{13}$

Respecting the elderly means respecting human life as a whole. Human society has been and will be developing from generation to generation. Therefore, the elderly should enter their old age with security and dignity. Realizing the great potential of ageing in the contemporary world, the CRE would be adopted.

\section{Universality and Specialization}

Human rights are universally respected by the world beyond civilizations, races and individual differences. ${ }^{14}$ The Universal Declaration of Human Rights ("UDHR") declares: "Everyone is entitled to all the rights and freedoms set forth in this Declaration, without distinction of any kind, such as race, colour, sex, language, religion, political or other opinion, national or social origin, property, birth or other status." 15 The universality of human rights is based on the protection of minorities. ${ }^{16}$ Since 1945, the UN has assumed the important task of universal human rights protection. The UN has not only developed most international human rights standards, but has also created a complex system of universal bodies and procedures to monitor observance of human rights, such as working groups, experts and special rapporteurs on different themes.

Meanwhile, human rights are particularly manifested in the different circumstances. ${ }^{17}$ Different historical traditions, religious beliefs, cultural concepts, values, resource status and economic factors lead to the diversification of the civilization in different countries and regions. Therefore, the universal acceptance of human rights standards does not mean that human rights are identical at any time, in any country, but the modes of human rights protection of all countries must be identical. ${ }^{18}$ The universality of human rights does not deny the reasonable discrimination in human society in which an individual rights are restricted because of different identities and personal

13 S. Pinghua, On the Protection and Implementation Mechanism of Regional Human Rights, 4 Am. J. Heze UnIv. 32 (2010).

14 W. Xigen, Epidemical discrimination violates spirit of human rights, CHINA DAILY, Feb. 20, 2020, at A1, available at http://www.chinadaily.com.cn/a/202002/20/WS5e4e77d5a310128217279140.html.

15 UDHR art. 2, available at https://www.un.org/en/universal-declaration-human-rights/index.html.

16 Q. Yanping, Human Rights and Rule of Law [人权与法治] 44 (2003).

17 B. Guimei, Human Rights Law [人权法学] 26 (2d ed. 2015).

18 T. Zwart \& N. Al Haider, Safeguarding the Universal Acceptance of Human Rights through the Receptor Approach, 36 Hum. RTs. Q. 899-902 (2014). 
abilities in pursuit of the substantive rule of legal theory and the requirement of equality and social justice. ${ }^{19}$ Older people belong to this special subject group.

The construction of the rights system for the elderly should admit the inequalities caused by the differences, provide special recognition and convenience for the differences of their behavior ability or identity, and treat them differently. Special measures and protection for older persons should be adopted in line with the general human rights as an integral part of the rights of the elderly. It is because "one of the contents of human rights is that everyone has the right to live on their own, and when they cannot survive by themselves, they have the right to request assistance from the society, and the society must fulfill its obligation to enable its members to live and survive." 20

\section{The UN Human Rights Organs and Various Rights of the Elderly}

In recent years, the rights of the elderly have attracted much attention. The UN's several human rights organizations put forward lots of proposals on ageing issues to protect the rights of the elderly.

\section{A. The Human Rights Council}

Since 2009, the Human Rights Council has focused on integrating the rights of older persons into the human rights framework to address the growing problem of ageing. The rights of the elderly have been raised in several reports.

(a) Report of the Human Rights Council Advisory Committee on the Human Rights of the Elderly

In 2009, the Human Rights Council Advisory Committee submitted to the Human Rights Council a working paper entitled, "The Necessity of a Human Rights Approach and Effective United Nations Mechanism for the Human Rights of the Older Person." ${ }^{21}$ The working paper has promoted a full study on the discrimination

19 J. Donnelly, The Relative Universality of Human Rights, 29 Hum. RTs. Q. 281(2007).

20 Q. Ben, Theory of Market Rule of LAW [市场法治论] 314 (2002).

21 C. Chung (Member of the Human Rights Council Advisory Committee), The Necessity of a Human Rights Approach and Effective United Nations Mechanism for the Human Rights of the Older Person,4th Session of Human Rights Council Advisory Committee, U.N. Doc. A/HRC/AC/4/CRP.1 (Jan. 25-29, 2010), available at https://www.ohchr.org/ 
of older persons to establish an international convention on the human rights of older persons. ${ }^{22}$ It has finally formed a list of 15 rights of the elderly integrating the discussions of HelpAge International, Yale Law School and the UN International Law Commission. The 15 rights are as follows: right to be free from discrimination; right to freedom from violence and abuse; right to equal treatment before the law; right to dignity; right to health; right to food, water, shelter, and clothing; right to work and financial independence; right to property; right to social security; right to freedom of thought, conscience, and religion; right to freedom of opinion and expression; right to autonomy; right to participate in public affairs; right to education; and right to be free of practices that infringe upon their rights. ${ }^{23}$

\section{(b) Report of the Special Rapporteurs of the Human Rights Council on the Right to Health of the Elderly}

The mandate of the Special Rapporteur on the right of everyone to the enjoyment of the highest attainable standard of physical and mental health was originally established by the Human Rights Commission in April 2002 following Human Rights Council Resolution 2002/31. ${ }^{24}$ Based on this study, the Human Rights Council held a panel discussion on the right to health of older persons in September 2011, focusing on the increasing challenges faced by older persons and an opportunity to identify good practices and possible measures. ${ }^{25}$

The report emphasizes that the right to health is essential in the establishment, implementation, monitoring and evaluation of health-related policies and programs in order to mitigate the impact of an ageing society and ensure the enjoyment of this human right by older persons. ${ }^{26}$ The report also points out that encouraging older persons to be physically, politically, socially and economically active is beneficial not only to the elderly themselves, but also to human society as a whole. It concludes that the promotion and protection of the human rights of the elderly should be a concern

EN/HRBodies/HRC/AdvisoryCommittee/Session4/Pages/Index.aspx.

22 OHCHR, Historical Background of The Establishment of the Mandate, available at https://www.ohchr.org/EN/ Issues/OlderPersons/IE/Pages/Background.aspx.

23 Supra note 21, at 21-4.

24 A. Grover, Thematic report of the Special Rapporteur on the Right of Everyone to the Enjoyment of the Highest Attainable Standard of Physical and Mental Health on the Realization of the Right to Health of the Elderly,18th Session of Human Rights Council, U.N. Doc. A/HRC/18/37 (July 4, 2011), available at https://undocs.org/a/hrc/18/37.

25 HelpAge International, Health and Human Rights of Older Persons: Challenges and Opportunities (Sept. 16, 2011), available at https:/www.ohchr.org/_layouts/15/WopiFrame.aspx?sourcedoc=/Documents/Issues/OlderPersons/Right tohealth_HRC16Sept2011-Helpage.doc\&action=default\&DefaultItemOpen=1.

26 Supra note 24. 
of everyone, as entering the age stage is a process involving all people. ${ }^{27}$

\section{(c) Report of the Independent Expert on Human Rights and Extreme Poverty}

In 2010, the independent expert on human rights and extreme poverty focused on the role of the social security system in eliminating extreme poverty and promoting the human rights of older persons. The independent expert adopted a report focusing on the so-called "social pension," which is the non-contributory pension. Considering the vulnerability of older persons, States must take appropriate measures to develop a social security plan without discrimination; to provide benefits to all older persons; and to ensure equal rights for men and women. This report ensures that non-contributory pensions comply with core human rights standards. The role of international assistance and cooperation in the field of social security is also discussed. $^{28}$

\section{(d) Report of the Independent Expert on the Enjoyment of All Human Rights by Older Persons}

In 2014, the independent expert has chosen a comprehensive approach to ageing, covering relevant work in the field of international law and policy. ${ }^{29}$ As a prerequisite for assessing under-implementation and best practices, the independent expert lists the specific rights of older persons based on the traditional classification of human rights as follows.

The civil rights of the elderly include the rights of equality and freedom from age discrimination, the right to life and the dignified right to death, the right to physical, mental and emotional integrity, the right to legal personality and capacity for conduct, and the right to proper treatment. The political rights of the elderly include the right to participate in the social, cultural and political life of the community. The social rights of the elderly include the right to income security, the right to improve functional health, and the right to continue to receive various professional education in public and private institutions. The economic rights of the elderly include the right

27 Id.

28 M. Karmona, Report of the Independent Expert on Human Rights and Extreme Poverty, 17th Session of the Human Rights Council, U.N. Doc. A/HRC/17/34 (Mar. 17, 2011), available at https://documents-dds-ny.un.org/doc/UNDOC/ GEN/G11/118/72/PDF/G1111872.pdf?OpenElement.

29 R. Kornfeld-Matte, Report of the Independent Expert on the Enjoyment of All Human Rights by Older Persons, 27th Session of Human Rights Council, U.N. Doc. A/HRC/27/46 (Sept. 8, 2014), available at https://www.ohchr.org/ EN/HRBodies/HRC/RegularSessions/Session27/_layouts/15/WopiFrame.aspx?sourcedoc=/EN/HRBodies/HRC/ RegularSessions/Session27/Documents/A-HRC-27-46_en.doc\&action=default\&DefaultItemOpen=1. 
to housing and to a healthy environment and the right to work. ${ }^{30}$

In 2015, the Independent Expert provides an overview of the existing international and regional human rights standards and analyzes the two key concepts, as well as their scope in another report. The Independent Expert offered many beneficial recommendations to help States implement appropriate and effective frameworks which is used for strengthening the autonomy of older persons, ensuring their active involvement and participation in all spheres of life and improving their health and quality of life, as well as promoting a human rights-based approach to care settings. ${ }^{31}$

\section{B. The UN High Commissioner for Human Rights}

In recent years, the Office of the High Commissioner for Human Rights ("OHCHR") has noticed that the elderly is facing universal and special human rights challenges worldwide, and has repeatedly raised the issue of the rights of the elderly in the form of thematic reports.

\section{(a) Report Submitted to Open-ended Working Group on Ageing ${ }^{32}$}

In 2011, the OHCHR submitted a report entitled, "Human Rights of Older Persons: International Human Rights Principles and Standards" to the first working conference of the Open-ended Working Group on Ageing as a background document. The report points out that the human rights of older persons face special challenges across the globe, including a wide range of civil, economic, political, social and cultural rights. The report summarizes and analyzes the rights and problems of the elderly in existing human rights conventions, including non-discrimination, protection of the rights of older women, vulnerability and special protection measures of the elderly, special protection measures for special groups, the right to social security and the issue of social protection, universal design and accessibility and the right to health and adequate housing. ${ }^{33}$

32 G.A. Res. 65/182 (Apr.18-21, 2011): Human Rights of Older Persons: International Human Rights Principles and Standards, Background Paper-revised and updated, available at https://www.ohchr.org/EN/Issues/OlderPersons/Pages/ Submissions.aspx.

33 Id. at 2. 
(b) Report of "Normative Standards in International Human Rights Law in Relation to Older Persons" - Analytical Outcome Paper ${ }^{34}$

This report provided a further legal analysis of the applicable standards of rights for the elderly at the international level at the Third Working Session of the Open-ended Working Group on Ageing held in New York in 2012. At the level of international human rights law, the existing rights of the elderly have obvious problems of inadequacy arising from normative gaps and fragmentation, as well as a lack of the coherence and specificity of standards consistent with the characteristics of the elderly. ${ }^{35}$ It shows a clear complementarity between the regional and the international approaches to the protection of the rights of older persons. In this report, the UN is required to make a comprehensive and systematic approach, at all levels, to protect the human rights of older persons. ${ }^{36}$

\section{(c) Report Submitted to the Economic and Social Council ${ }^{37}$}

This report analyzes the existing international instruments and gaps in the regime of protecting the rights of the elderly, and offers an analysis of the human rights situation of the elderly in the light of the indivisible, interdependent and interrelated nature of all human rights. ${ }^{38}$ It also points out that older persons face particular and urgent challenges against human rights, such as ageism, long-term care, violence and abuse, social protection and the right to social security, access to productive resources, work and food and housing. ${ }^{39}$ Each of these challenges relates equally to civil, cultural, economic, political and social rights, which are exacerbated by normative and implemented gaps in protection. These challenges raise a series of issues worthy of in-depth analysis and regulation. ${ }^{40}$

\section{The Open-ended Working Group on Ageing}

The Open-ended Working Group on Ageing was established by the UN General

34 OHCHR, Normative Standards in International Human Rights Law in Relation to Older Persons, Analytical Outcome Paper (Aug.2012), available at https://social.un.org/ageing-working-group/documents/OHCHRAnalytical OutcomePaperonOldePersonsAugust2012.doc.

35 Id. at 3 .

36 Id.

37 UN ECOSOC, Report of the United Nations High Commissioner for Human Rights, the Substantive Session of 2012, U.N. Doc. E/2012/51 and Corr.1 (July 23-27, 2012), available at https://www.un.org/ga/search/view_doc. asp?symbol=E/2012/51.

$38 \quad I d$. at 2.

39 Id. at 17.

40 Id. 
Assembly Resolution 65/182 on December 21, 2010. Its mandate called for considering the existing international framework on the human rights of older persons and the identification of possible gaps and the best way to address them, including the feasibility of further instruments and measures. ${ }^{41}$ From its first session in 2011 to April 2019, the Working Group has held ten working sessions. The first three sessions focused on the human rights situation of the elderly worldwide, and examined the concerns of the elderly in the framework of existing international human rights and the implementation of their rights. Beginning with the fourth working session in 2012, as mandated by the General Assembly at its 67th session, the discussions turned to the rights which were not sufficiently addressed in existing content of the elderly's human rights. ${ }^{42}$ In 2015, the Working Group held its 6th Working Session for the purpose of strengthening the protection of the human rights of older persons. ${ }^{43}$ Until now the Working Group has mainly focused on the following issues regarding the rights of older persons such as: right to non-discrimination; right to health; right to anti-violence and abuse; right to social protection and security; right to independence; and right to hospice care. ${ }^{44}$

\section{The UN Specialized Agencies}

\section{(a) International Labor Organization}

The ILO has been concerned about the protection of the rights of the elderly for such a long time. As early as 1933, it formulated Old-Age Insurance (Industry, etc.) Convention (No.35) and Old-Age Insurance (Agriculture) Convention (No.36). It then adopted Invalidity, Old-Age and Survivors' Benefits Convention in 1967. Subsequently, the scope of the protected persons, the model of payment and the methods of calculation have been stipulated. However, the ILO pays little attention to the implementation of the rights of the elderly. It was not until 1980 when the Recommendation concerning Older Workers-R162 was passed that ageism was clearly identified as a form of discrimination. ${ }^{45}$ The proposal calls on all countries

41 G.A. Res. 65/182, U.N. Doc. A/RES/65/182 (Feb. 4, 2011), available at https://www.ohchr.org/EN/Issues/ OlderPersons/Pages/Submissions.aspx.

42 United Nations Department of Economic and Social Affairs (UNDESA), Reports of Previous Working Sessions (Aug. 12-15, 2013), available at https://social.un.org/ageing-working-group/fourthsession.shtml.

43 Report of the Open-ended Working Group on Ageing on its Organizational Session, on the 6th Working Session, U.N. Doc. A/AC.278/2015/2 (July 14-16, 2015), available at https://undocs.org/A/AC.278/2015/2.

44 UNDESA, 11th Open-ended Working Group on Ageing for the purpose of strengthening the protection of the human rights of older persons (Apr. 6-9, 2020), available at https://social.un.org/ageing-working-group/eleventhsession.shtml.

45 ILO, R162 - Older Workers Recommendation, 1980 (No. 162), available at https://www.ilo.org/dyn/normlex/en/f?p=N ORMLEXPUB:12100:0::NO::P12100_ILO_CODE:R162. 
to take measures to prevent discrimination (employment and occupation) so as to promote equal opportunities and treatment for all workers, whatever their age. ${ }^{46}$ In addition, both the Recommendation and the Termination of Employment Convention 1982 emphasize that age should not constitute a legitimate reason for termination of employment, except for retirement in accordance with national laws and practices. ${ }^{47}$

\section{(b) The World Health Organization}

'Ageing' is a health theme of the World Health Organization ("WHO"). As regard ageing, the WHO mainly works in three aspects: prevention of chronic diseases; access to primary health care for the elderly; and creation of an environment conducive to the elderly. ${ }^{48}$ In 1990, the WHO put forward the goal of "healthy aging., ${ }^{, 99}$ On the International Year of Older Persons in 1999, the WHO put forward the slogan of "active ageing" which refers to the process of improving the quality of life in old age and maximizing opportunities for health, participation and security, which is suitable for individuals and people..$^{50}$ Currently "active ageing" is more widely expressed than "healthy ageing."

\section{Rights of the Elderly to be Recognized and Included}

The human rights system should be logically classified. However, "delineating the classification and system of human rights not only has the meaning of knowledge, but also has the value of perfecting the content of Human Rights. ${ }^{, 51}$ The CRE must adopt a comprehensive and systematic approach to protect and promote the human rights of the elderly with big data. Based on the traditional classification of human rights, this article lists the specific rights that the elderly should enjoy.

46 Id.

47 ILO, R166-Termination of Employment Recommendation, 1982 (No. 166), available at https://www.ilo.org/dyn/ normlex/en/f?p=NORMLEXPUB:12100:0::NO::P12100_ILO_CODE:R166.

48 WHO, Population ageing, available at https://www.who.int/news-room/q-a-detail/population-ageing.

49 WHO, Ageing and life-course, available athttps://www.who.int/ageing/healthy-ageing/en.

50 WHO, Discussion on the Realization of the Right to Health of Older Persons, 18th Session of the UN Human Rights Council Panel (Sept. 16, 2011), available at https://m.reliefweb.int/report/447272.

51 Q. Xianglin, How Far are Human Rights from Us [人权离我们有多远] 181 (2015). 


\section{A. Civil and Political Rights}

\section{(a) The Right to Life}

The right to life is critically important for each individual. It is the most fundamental right among all rights, which has become a self-evident consensus. Both Article 3 of the UDHR and Article 6 of the ICCPR recognize and protect the right to life of all persons, which is defined as the highest human right and placed at the forefront of substantive rights. The right to life is inherent, non-transferable and nonrenounceable, therefore it is expressed in the ICCPR as 'has' rather than "should have."

The elderly's right to life should be protected from dignity and autonomy under international human rights law. ${ }^{52}$ The elderly has the right to take care of their own lives independently and to seek to realize the value of life in a reasonable and dignified manner. ${ }^{53}$

Older persons should not be regarded as useless or incomplete for their age and physical incompleteness. Their value should not be distinguished from that of young age. State is obliged not to arbitrarily deprive the elderly of their lives and the positive obligations. $^{54}$

\section{(b) The Right to be Free from Discrimination}

The reality of widespread discrimination against the elderly has become the consensus of the international community. Such discrimination occurs in all areas of the life and exists in many forms. It may also be based on gender or other factors, such as disability, health or social and economic conditions, habitation, marital status and ethnic or religious backgrounds which usually results in multiple discrimination. ${ }^{55}$ Age-based discrimination is often the root of the isolation and exclusion of older persons, who are considered to be unproductive. Ageism is also closely linked to violence and abuse, in both public and private. However, exiting international human rights instruments do not explicitly prohibit ageism or multiple discrimination against older persons and the ten UN Treaty bodies ${ }^{56}$ do not often

52 W. Guanghu, Human Rights Law [人权法学] 158 (2015).

53 L. Hui, On the Right to Life and Euthanasia [试论生命权与安乐死权], 6 J. Shanghai Univ. (Soc. ScI. Ed.) [上海大学学 报(社会科学版)] 134 (2008).

54 ICCPR art. 6(4), available at https://www.ohchr.org/EN/ProfessionalInterest/Pages/CCPR.aspx.

55 HelpAge International, Discrimination in Old Age: Multiple, Cumulative and on the Increase (Aug. 1, 2011), available at https://social.un.org/ageing-working-group/documents/HelpAge $\% 20$ briefing $\% 20$ discrimination $\% 20 \mathrm{in} \% 20 \mathrm{old} \% 20$ age $\% 20$ Aug\%2011.pdf.

56 Human Rights Committee; Committee on Economic, Social and Cultural Rights; Committee on the Elimination of Racial Discrimination; Committee on the Elimination of Discrimination Against Women; Committee Against Torture; 
address this issue during the Universal Periodic Review. ${ }^{57}$ Hence, there is a need to craft a new convention specifically targeting older persons.

The CRE should reiterate the principle of "equality before the law" stipulated in the core human rights treaties. Domestic laws should also prohibit all agebased discrimination in any form or for any reason in any place and under any circumstances. The government should also take reasonable and positive actions to facilitate the elderly in order to promote equality and eliminate discrimination.

\section{(c) The Right to be Free from Exploitation, Violence and Abuse}

Exploitation, violence and abuse are major challenges to the elderly, which result in lifelong disability, malnutrition, drug or alcohol dependence, and lower immune system responsiveness. They are also prone to self-injury or self-neglect, fear and anxiety, susceptibility to depression, suicidal tendencies and even death. ${ }^{58}$

Studies showed that 3-10 percent of older persons have been ill-treated. In Canada, for example, the most common form of abuse is the indolence of care in community and family. In the reported cases of abuse, 55 percent of the older persons are neglected, 15 percent are related to physical abuse, and 12 percent are economic exploitation. The statistics on ill treatment collected in less developed areas are relatively limited. In a sample survey conducted in rural areas, 40 of 1000 people were physically abused. In another small sample survey conducted with 500 older persons aged 70 and above in an urban environment, 20 percent could not receive good care at home. ${ }^{59}$

Although the UDHR provides for the core rights of all persons in the civil, political, social, economic and cultural fields and forms the basis of international human rights law legislation, the right to freedom from exploitation, violence and abuse is not included in the norms of human rights standards. International human rights law has not yet kept eyes on these forms of human rights violation to older persons in different institutional, community and family environments.

Committee on the Rights of the Child, Committee on Migrant Workers; Committee on the Rights of Persons with Disabilities; and Sub-Committee on the Prevention of Torture and Committee on Enforced Disappearances.

57 See the Speech of Bridget Sleap (senior rights policy adviser at HelpAge), 26th Session of the Human Rights Council (June 26, 2014), available at http://ohchr.org/EN/HRBodies/HRC/RegularSessions/Session26/Pages/Documentation. aspx.

58 S. Danell, The Relationship between Abuse, Psychosocial Factors, and Pain Complaints among Older Persons in Europe, 50 Medicine 61-74 (June 6, 2014).

59 UNDESA, Human Rights: Elder Abuse, available at https://www.un.org/chinese/esa/ageing/humanrights36.htm. 


\section{(d) The Right to Expression}

The right to freedom of expression is mainly based on human nature and its needs. Article 19 of the UDHR stipulates the right to expression. ${ }^{60}$ The right to expression should be also guaranteed for the elderly as an independent and free person. It is conducive for them to realizing social integration of the elderly, changing the negative views of the society on the elderly, and enabling them to express their views and decisions on matters affecting their lives in their families, communities and countries. ${ }^{61}$ It is a necessary condition and prerequisite for the elderly to live with dignity and implement other civil and social rights.

\section{(e)The Right to Privacy}

Privacy refers to the right of individuals to live according to their own wishes and requirements, including the right to isolate from their peers or withdraw from public life in order to maintain their private living space. ${ }^{62}$ The right to privacy has developed into a new right whose value lies in safeguarding human dignity and individual freedom. Taiwanese scholar Wang Zejian also include human dignity, self-determination, emotional release, self-assessment, and limited and protected communication. ${ }^{63}$ The right to privacy should include private life, family, residence, communication and personal honor and reputation. ${ }^{64}$

The privacy of the elderly should be also protected on the basis of equality with others. Their personal information and health care data of the elderly should not be interfered arbitrarily or unlawfully. Both structured and non-structured sources of privacy are manipulated by big data technology which effect many aspects of the elderly's activities. Therefore, the CRE should specially and clearly protect the right to privacy of the elderly in the context of big data.

\section{(f) The Right to Housing and Family Life}

In recent, the proportion of elderly people living alone has increased in many parts of the world. Under such circumstance, loneliness and social isolation are relatively

60 UDHR art. 19. It provides: "Everyone has the right to freedom of opinion and expression; this right includes freedom to hold opinions without interference and to seek, receive and impart information and ideas through any media and regardless of frontiers."

61 Freedom of Expression Institute, Promoting and Defending the Constitutional Right to Freedom of Expression, available at $\mathrm{https}: / /$ www.fxi.org.za.

62 A. Marmor, What Is the Right to Privacy?, 43 Philosophy \& Pub. Aff. 3 (2015).

63 W. Zejian, The Specification of Personality Rights and Its Protection Scope, Privacy Chapter (I) [人格权的具体化及其 保护范围·隐私权篇(上)], 6 COMP. L. Res.[比较法研究] 2 (2008).

64 L. Yankwich, Right of Privacy: Its Development, Scope and Limitations, 27 Notre Dame L. Rev. 517-20 (1952). 
common among the elderly.

The right to housing and family life for the elderly includes the right to legal recognition of family relations, as well as the right of a family to live together and enjoy each other's companionship. ${ }^{65}$ Thus, the elderly can make their own decisions regarding the lifestyle, including marital autonomy, reproductive autonomy, the right to receive guardianship and the right to equality with other family members. In this regard, the State government should take effective and appropriate measures to eliminate discriminations against the elderly in all forms mentioned above and establish a family support system to strengthen the capacity of family members to care for older persons. Such a long-term support system will increase a number of the elderly under abandonment, neglect, violence, abuse and segregation by family members.

\section{(g) The Right to Judicial Remedy}

The right of judicial remedy includes the following two basic elements: the right to appeal to the court and the right to a fair trial. The main manifestations are due process and access to fair jurisdiction. ${ }^{66}$

At the national level, most lawsuits concerning the elderly focus on the "right to pension." Without administrative procedures, the pension of the elderly may not be available. ${ }^{67}$ Other key rights affecting the elderly, such as the legitimacy of guardianship orders, need due process to protect them. In addition, the right of judicial relief for the elderly in prison is also worthy of attention. The rise in the number of elderly people in prison poses a series of new challenges. The safe imprisonment for the elderly requires a completely different conditions, such as extra clothing in winter, accessible facilities in prisons, especially peaceful stay in prison without violence and extortion. There are also chronic diseases, disability-related diseases and end-stage diseases caused by Alzheimer's disease. Prisons in many countries are often struggling to cope with these diseases due to lack of resources, poor planning and lack of training for staff. ${ }^{68}$ These challenges have not yet been addressed by the UN treaty monitoring bodies.

65 R. Bratt \& M. Stone, A Right to Housing: Foundation for a New Social Agenda 177 (2006).

66 K. McCracken, Commentary on the Basic Principles and Guidelines on the Right to a Remedy and Reparation for Victims of Gross Violations of International Human Rights Law and Serious Violations of International Humanitarian Law, 76 Relations Internationales 54 (2005).

67 H. Comijs et.al., Elder Abuse in the Community: Prevalence and Consequences, 46 J. Am. Geriatrics Soc. 885-8 (Aug. 1, 2015).

68 US Human Rights Watch, Old Behind Bars: The Aging Prison Population in the United States 24 (2012), available at https:/www.hrw.org/sites/default/files/reports/usprisons0112webwcover_0.pdf. 


\section{B. Economic, Social and Cultural Rights}

Like civil and political rights, economic, social and cultural rights are an integral part of international human rights law. It is however undeniable that the typical civil and political rights are not indistinguishable from economic, social and cultural rights. This difference is largely based on the role of the State: for civil and political rights, the main emphasis is on freedom from State interference, while, for economic, social and cultural rights, the main factor to be considered is the right to seek protection and assistance from the State. ${ }^{69}$ As a special vulnerable group in society, the elderly is the main recipients of economic, social and cultural rights.

\section{(a) The Right to an Adequate Standard of Living}

An adequate standard of living is accepted by most international human rights conventions as a fundamental right to human being. Food, clothing and housing are the components of living. 'Adequacy,' from a purely material point of view, means living above the poverty line of society. ${ }^{70}$ According to the World Bank, the social poverty line consists of two parts: the cost of purchasing the lowest standard of food and other necessities and the cost of purchasing more things, both of which reflect the cost of participating in the daily life of society. The latter number varies from country to country. ${ }^{71}$

Recently, one of the most pressing challenges to the elderly is poverty and inadequate living conditions. ${ }^{72}$ Therefore, it is particularly important to clarify the right of the elderly to an adequate standard of living. ${ }^{73}$ The realization of the right of the elderly to an adequate standard of living needs to be guaranteed by regulating the responsibility of the State in the CRE. Firstly, the State should recognize the right of the elderly by law to an adequate standard of living for themselves and their families, including adequate food, clothing and housing for their livelihood and survival. Secondly, the State should take appropriate steps to prevent ageism that may arise in realizing this right by older persons.

The right to an adequate standard of living also requires to supply the older

69 E. Riedel, International Covenant on Economic, Social and Cultural Rights(1966), 12 ConTEMP. PAC. 359 (2016).

70 M. Kothari, Report of the Special Rapporteur on Adequate Housing as a Component of the Right to an Adequate Standard of Living, and on the Right to Non-Discrimination in this Context, 31st Session of Human Rights Council (Dec. 30, 2015), available at https://www.refworld.org/pdfid/56c57da84.pdf.

71 IBRD, World Development Report 1990, available at https://openknowledge.worldbank.org/handle/10986/5973.

72 S. Lee, Factors Affecting Social Participation of the Elderly Living in Poverty, 24 Korean J. Commun. Living Sci. 343 (2015).

73 UDHR art. 25 \& ICESCR art. 11. 
people with the social protection through legislation or national policies. ${ }^{74}$ To realize this right, it is necessary to ensure equal access to food and potable water and to provide assistance in price and services to meet the relevant needs of older persons. ${ }^{75}$ In addition, the right of the elderly to an adequate standard of living should also place special emphasis on the principle of care. Also, the elderly, especially the older women and the disabled older persons, should be protected under poverty reduction policies when necessary. The elderly and their families in poverty should have access to the public housing programs equally effective. Finally, every older person should be able to participate in the national retirement program to enjoy retirement benefits. ${ }^{76}$

\section{(b) The Right to Work}

The right to work is not only to guarantee the material resources for living, but also realize all-round development of human beings. The right to work is closely related to human dignity, social justice and harmony as an inherent part of human dignity.

In order to realize the right to work of the elderly, the CRE can refer to the model of the Convention on the Rights of Persons with Disabilities ("CRPD"). Firstly, the State should recognize the right of the elderly to work and the right to choose or accept work freely for their livelihood equally. For this purpose, labor market should be regulated for open and inclusive working environment to eliminate the obstacles to the elderly. Secondly, the States Parties should take appropriate steps, including legislation to prohibit discrimination on the basis of age. In addition, the right to work of the elderly should include the right of equal remuneration for equal value work, the right to a safe and healthy working environment, the right to be free from harassment in the workplace, the right to appeal, the right to trade unions, the right to participate in general technical and vocational guidance programs, the right to vocational training and further training and the right to obtain employment services. ${ }^{77}$ It is necessary to further formulate policies to promote self-employment, entrepreneurship, the creation of cooperatives and individual business opportunities for the elderly. A famous example of the elderly being entrepreneurial is the King of Orange-Chu Shijian who started orange market by the Internet at the age of 75 years old to become billionaires. ${ }^{78}$

74 F. Miller \& A. Vandome, Right to an Adequate Standard of Living 3 (2011).

75 Id.

76 K.Y. Kong, “All for Some' or 'Some for All?" Assessing the Realization of the Right to Social Welfare in the Retirement Protection Reform in Hong Kong, 3 Hong Kong L. J. 779 (2017).

77 Convention on the Rights of Persons with Disabilities, art. 27.

78 Steven, 'Chu oranges,' the King of Orange, China DAILy, Oct. 27, 2015, available at http://www.newsgd.com/ livingingd/2015-10/27/content_135634087.htm. 


\section{(c) The Right to Health}

The right to health is an inclusive right. The General Comment No. 14 of the Committee on Economic, Social and Cultural Rights stipulates:

The right to health contains both freedoms and entitlements. Freedoms include the right to control one's health, including the right to be free from non-consensual medical treatment and experimentation. Entitlements include the right to a system of health protection [...] that provides equality of opportunity for people to enjoy the highest attainable standard of health. The basic determinants of health" includes: access to safe and potable water and adequate sanitation, healthy occupational and environmental conditions, and access to health-related education and information, including on sexual and reproductive health. ${ }^{79}$

On September 16, 2011, the WHO participated in a panel discussion on the thematic study on the realization of the right to health of older persons. This study, urging a paradigm shift, shows that human society should move beyond a simple search for healthy ageing by its citizens and begin working towards active and dignified ageing, which is planned and supported just like any other stage of the individual's life-course. ${ }^{80}$ Active and dignified ageing for older persons requires reframing social concept of ageing to put more focus on the continued participation of older persons in social, economic, cultural and civic life, as well as their continuous contributions to society. ${ }^{81}$

The right to health of the elderly should be based on the principles of dignity, independence and care, focusing on primary health care and chronic diseases, longterm care, palliative care and informed consent. ${ }^{82}$

\section{(d) The Right to Social Security}

Social security means that through legislation, the State actively mobilizes resources from all aspects of society to ensure the survival of citizens who have no income, low income or who have suffered various unexpected difficulties such as unemployment,

79 Committee on Economic Social and Cultural Rights, General Comment No.14 on the Right to the Highest Attainable Standard of Health, U.N. Doc. E/C.12/2000/4, ๆ 25 (Aug. 11, 2000).

80 WHO, Panel Discussion on the Realization of the Right to Health of Older Persons, 18th Session of the UN Human Rights Council (Sept. 16, 2011), available at https://www.ohchr.org/Documents/Issues/OlderPersons/WHO Panelevent11Sep2011.doc.

81 Id.

82 A. Grover, Thematic Study on the Realization of the Right to Health of Older Persons by the Special Rapporteur on the Right of Everyone to the Enjoyment of the Highest Attainable Standard of Physical and Mental Health, 18th Session of the UN Human Rights Council, U.N. Doc. A/HRC/18/37 (July 4,2011), available at https://undocs.org/a/hrc/18/37. 
sickness, work-related injuries and the burden of raising up children. At the same time, the level of public welfare and the quality of life of the people shall be gradually improved in accordance with economic and social development. ${ }^{83}$

In general, as people get older, there will be fewer sources of income from work. Except for those highly educated professionals who may always be able to earn high salaries, most of older people struggle to maintain or attain well paid positions. People differ in terms of savings and assets, but most of them do not have adequate income security to maintain an adequate standard of living in their old age. Although another source of income for the elderly is to obtain financial help from other family members, this source is unreliable and far from meeting the needs of life, especially for low-income families. ${ }^{84}$ Today, public pension is the most important source of income security to solve this problem. According to the OECD, 59 percent of household income of the elderly over 65 years old comes from public pensions, 24 percent from self-reliance, and 17 percent from capital gains mainly of private pensions. ${ }^{85}$ The specific level varies from country to country and from region to region. In some non-OECD countries, public pension coverage may be lower which has no effect on household income. Most of the elderly in these countries have to live on their own even though they can no longer move. In this case, the elderly used to fall into poverty. ${ }^{86}$

The right to social security must be incorporated into the CRE. Without a strong legal and institutional framework as well as a long-term strategy, human rights of the elderly will be seriously threaten. A sound legal framework is thus necessary to prevent political manipulation and to ensure the long-term participation of national authorities. It also allows the elderly to know what their rights and corresponding standards are.

\section{(e) The Right to Education}

The right to education has many facets, such as freedom of education and academic research. It is an indispensable part of contemporary human rights law which is

83 W. van der Klaauw \& K. Wolpin, Social Security and the Retirement and Savings Behavior of Low-income Households, 145 J. ECONOMETRICS 21 (2008).

84 ILO, World Social Protection Report 2014/15: Building Economic Recovery, Inclusive Development and Social Justice, available at http://www.ilo.org/global/research/global-reports/world-social-security-report/2014/WCMS 245201/lang--en/index.htm.

85 OECD, Pensions at a Glance 2013:Retirement-income systems in OECD and G20 countries (Jan. 20, 2015), available at $\mathrm{http}: / /$ www.oecd.prg/pensions/pensions at a glance.htm.

86 Id. 
usually regarded as a cultural right. ${ }^{87}$ Few international human rights instruments mention the protection of the right of older persons to education. In the past few decades, although literacy and education levels in the world have risen significantly, the scores for the elderly is still much lower than those of the younger generation. Literacy levels of people aged 65 and above are as high as 97 percent in the more developed areas, while as low as 54 percent in less developed countries. In Africa, the literacy rate is 43 percent for older men; 22 percent for older women aged 65 and above; 71 percent for older men and 47 percent for older women in Asia, 77 percent for older men and 71 percent for older women in Latin America and the Caribbean. ${ }^{88}$ In addition, the literacy and education level of rural areas in most countries are lower than those of urban areas. It is also rare for employers to provide training opportunities for older workers. The elderly should clearly enjoy the right to education, including cultural training, equal educational opportunities, equal access to spiritual and entertainment resources.

\section{(f) The Right to Participate in Cultural Life}

Social segregation is a major challenge for the integration of the elderly into society. The right to participate in cultural life focuses on how to ensure the majority of the elderly contribute to cultural diversity. It is also conducive for the elderly to enjoy the benefits of social, economic and cultural progress and promote a positive image of the elderly contributing to the family and community. However, core international human rights treaties have not paid attention to the right of the elderly group to culture. $^{89}$

The right to participate in cultural life is closely related to other individual rights and fundamental freedoms, which includes freedom of expression, freedom of religion and belief, freedom of education, freedom of assembly and freedom of association. ${ }^{90}$

The CRE should clearly regulate the obligations and responsibilities of the State on the right to culture. The State should recognize the rights of older persons to participate in cultural life equally. All appropriate measures should be taken to lead

87 H. Hannelore, A Humanistic Approach to Education of Older Persons, 2 Educ. Gerontology 407 (1977).

88 UNESCO Institute for Statistics: Adult and Youth Literacy (Sept. 1, 2015), available at http://www.uis.unesco.org/ literacy/Documents/fs32-2015-literacy.pdf.

89 Z. Shuo, Research on the Social Isolation of the Urban Elderly in China and Its Influencing Factors [中国城市老年人 社会隔离现状与影响因素研究], 4 Population J. [人口学刊] 16 (2015).

90 M. Land, Intellectual Property Rights and the Right to Participate in Cultural Life, New York Law School Institute for Information Law and Policy White Paper Series 08/09 \#02 (Nov. 1, 2008), available at SSRN: https://ssrn.com/ abstract=1475430 or http://dx.doi.org/10.2139/ssm.1475430. 
older persons to media and places conducive for their participation in cultural life, such as cultural materials, TV programs, movies, theatres, museums, libraries, and the places of tourist service. Moreover, the elderly should have the opportunity to develop their creativity and intelligence in order to meet their own interests and enrich society.

\section{Conclusion}

Population ageing has become a trend of globalization which is irreversible. At the same time, older persons are facing more and more challenges such as discrimination, poverty and abuse that affect their human rights. Paying special attention to the rights of older persons is the best response to these challenges. However, the existing international human rights instruments for the protection of the right of the elderly are porous and lack of legal binding effect. The above analysis makes it clear that there is a need to adopt a new instrument, i.e., The UN Convention on the Rights of the Elderly to address these problems facing them. This article has just examined the construction of the right system of the CRE. It has pointed out that the CRE should build a unique framework of the rights of the elderly, including civil and political rights, as well as economic, social and cultural rights. All this is not exclusive, but mutually inclusive and interactive. Such a specific convention for older persons under international law will give them all kinds of protection necessary for the enjoyment of all their rights. 